\title{
Brunner's gland hamartoma: A rare cause of gastrointestinal bleeding - Case report and review of the literature
}

\author{
David R Stolpman MD ${ }^{1}$, Gordon C Hunt MD ${ }^{1}$, Brett Sheppard MD², \\ Hahn Huang $\mathrm{MD}^{3}$, Deepak V Gopal MD FRCP ${ }^{1}$
}

DR Stolpman, GC Hunt, B Sheppard, H Huang, DV Gopal. Brunner's gland hamartoma: A rare cause of gastrointestinal bleeding - Case report and review of the literature. Can J Gastroenterol 2002;16(5):309-313.

An unusual cause of upper gastrointestinal bleeding is described in a previously healthy 45-year-old man who was admitted to hospital with weakness and fatigue, and had experienced an episode of melena two days before admission. His medical and surgical history was unremarkable. Upon admission to hospital, he showed evidence of iron-deficiency anemia, with a hemoglobin concentration of $61 \mathrm{~g} / \mathrm{L}$ (normal range 135 to $175 \mathrm{~g} / \mathrm{L}$ ), a mean corpuscular volume of $73 \mathrm{fL}$ (normal range 85.0 to $95.0 \mathrm{fL}$ ) and a ferritin concentration of $1.0 \mu \mathrm{g} / \mathrm{L}$ (normal range in males 15 to $400 \mu \mathrm{g} / \mathrm{L}$ ). Upper gastrointestinal endoscopy revealed a $3.5 \mathrm{~cm}$ ulcerated submucosal mass in the third portion of the duodenum, for which mucosal biopsies were nondiagnostic. A subsequent endoscopic ultrasound revealed a $2.7 \times 4.0 \mathrm{~cm}$ hyperechoic, cystic, submucosal tumour in the third portion of the duodenum. Endoscopic ultrasound-guided fine needle aspiration revealed no malignant cells. The patient eventually underwent a resection of the third portion of his duodenum. Surgical pathology revealed that this tumour was a Brunner's gland hamartoma, $4.5 \mathrm{~cm}$ in its greatest dimension.

Key Words: Brunner's gland; Gastrointestinal bleeding; Harmartoma

\section{Hamartome des glandes de Brunner, cause rare d'hémorragie digestive : exposé de cas et examen de la documentation}

\begin{abstract}
RÉSUMÉ : Voici un cas inhabituel d'hémorragie digestive haute chez un homme de 45 ans, jusque-là en bonne santé, qui a été hospitalisé pour de la faiblesse et de la fatigue et qui avait présenté, deux jours auparavant, un épisode de méléna. Il n'y avait rien à signaler du côté de ses antécédents médicaux et chirurgicaux. Les examens sanguins à l'admission ont révélé des signes d'anémie ferriprive : hémoglobine de $61 \mathrm{~g} / \mathrm{l}$ (normale entre 135 et $175 \mathrm{~g} / \mathrm{l}$ ), volume globulaire moyen de $73 \mathrm{fl}$ (normale entre 85,0 et $95,0 \mathrm{fl}$ ) et ferritine de $1,0 \mathrm{mg} / \mathrm{l}$ (normale entre 15 et $400 \mathrm{mg} / \mathrm{l} \mathrm{chez} \mathrm{les}$ hommes). Une endoscopie du tube digestif supérieur a montré la présence d'une masse sous-muqueuse, ulcérée, de $3,5 \mathrm{~cm}$, dans la troisième partie du duodénum, mais les biopsies n'ont pas permis de poser de diagnostic. Une échographie a par la suite révélé la présence d'une tumeur cystique, sousmuqueuse, super-réfléchissante, de 2,7 x 4,0 cm dans le dernier tiers du duodénum, qui s'est avérée non maligne à la ponction-biopsie. Le patient a finalement été opéré et subi la résection de la troisième partie du duodénum, et l'examen en pathologie chirurgicale a montré qu'il s'agissait, en fait, d'un hamartome des glandes de Brunner, qui mesurait $4,5 \mathrm{~cm}$ dans sa partie la plus large.
\end{abstract}

${ }^{1}$ Division of Gastroenterology, ${ }^{2}$ Department of Surgery, and ${ }^{3}$ Department of Pathology, Oregon Health Sciences University, Portland, Oregon, USA

Correspondence: Dr Deepak V Gopal, PV-310, Division of Gastroenterology, Oregon Health Sciences University, 3181 SW,

Sam Jackson Park Road, Portland, Oregon, 97201-3098, USA. Telephone 503-494-0194, fax 503-494-7556, e-mail Gopalde@ohsu.edu

Received for publication December 6, 2001. Accepted April 15, 2002 
$\mathrm{B}$ runner's glands are named after Brunner, the Renaissance pathologist credited with first describing these structures in the late 17th century, after he noted glandular tissue in the proximal small intestine. These glands are located primarily in the deep mucosa and submucosa of the duodenum. They are most apparent proximally, and they decrease in number as the duodenum progresses distally (1). They function to protect the duodenal epithelium from the acid chyme that is delivered from the stomach; to do this they buffer the gastric efflux by secreting both an alkaline mucus as well as the paracrine hormone enterogastrone, which inhibits gastric acid secretion.

Brunner's gland hamartomas are infrequently occurring lesions, although they may represent as many as 5\% of all benign duodenal tumours (2). Autopsy series report the finding of benign small intestinal tumours in $0.16 \%$ of cases (3). Presenting features may include upper gastrointestinal bleeding in $40 \%$ or, rarely, duodenal or gastric outlet obstruction; in as many as $25 \%$ of cases, they are an incidental finding (4). Patients typically present with symptoms in the fifth and sixth decades of life, and these lesions may be found in people of all races. Most Brunner's gland hamartomas are smaller than $2 \mathrm{~cm}$ in diameter; larger tumours, as in the present case, are rare (5), although tumours as large as $10 \mathrm{~cm}$ have been reported (6). Although the natural history of this lesion is poorly defined, one recent case report noted a more than 20-year interval between the initial diagnosis and subsequent development of symptoms (upper gastrointestinal bleeding), suggesting an essentially benign clinical course (7).

\section{CASE PRESENTATION}

A 45-year-old white man was admitted to hospital with weakness, lightheadedness and fatigue. He had been asymptomatic until two days before admission, when he began to experience melena. Upon admission to hospital, his hemoglobin concentration was noted to be low, at $61 \mathrm{~g} / \mathrm{L}$, with a mean corpuscular volume of $72.9 \mathrm{fL}$ (normal range 85 to $95 \mathrm{fL}$ ) and a ferritin concentration of $1.0 \mu \mathrm{g} / \mathrm{L}$. A nasogastric lavage was negative, and results of his other laboratory tests, including those for electrolytes and liver function, were unremarkable. He had no significant medical, surgical or family history, and he denied the use of any prescription or over-the-counter medications. He was not a smoker, but he did drink up to four beers per day.

He received $5 \mathrm{U}$ of packed red blood cells over the next $24 \mathrm{~h}$, and his hemoglobin concentration rose to $105 \mathrm{~g} / \mathrm{L}$. Because of his obvious iron deficiency, there was concern about his chronic gastrointestinal blood loss, and he subsequently underwent colonoscopy and esophagogastroduodenoscopy.

The colonoscopy revealed moderate sigmoid diverticulosis, three small colonic polyps and prominent internal hemorrhoids. These findings were not thought to explain his microcytic anemia or melena. Panendoscopy revealed a $3.5 \mathrm{~cm}$, ulcerated, submucosal mass in the third portion of the duodenum, just beyond the ampulla of Vater (Figure 1).

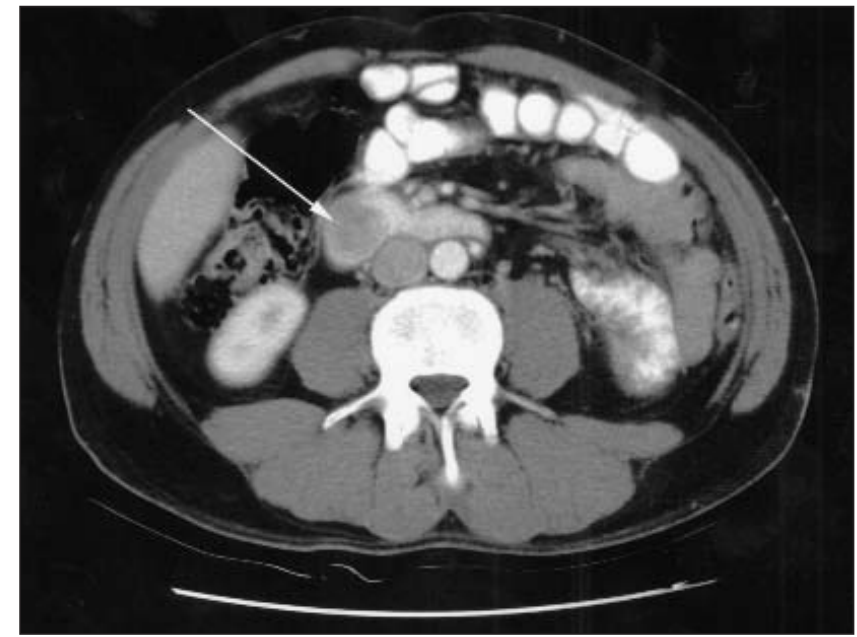

Figure 1) Image taken from an abdominal computed tomography scan revealing a large, hypoattenuating structure in the third portion of the duodenum (arrow)

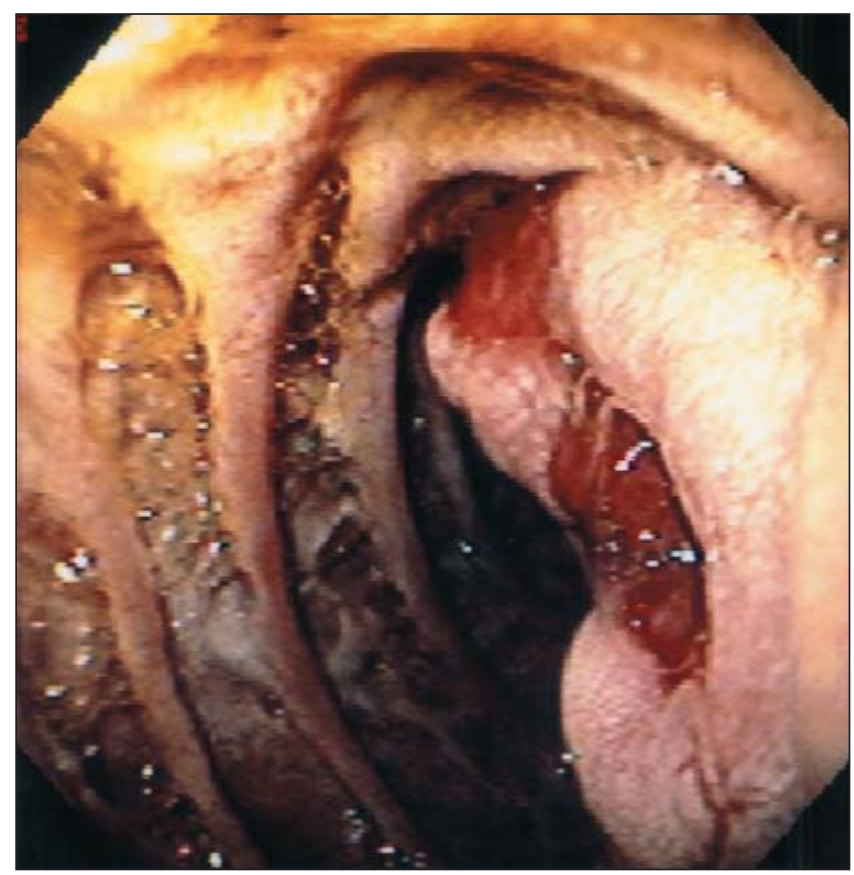

Figure 2) Endoscopic appearance of the large, ulcerating mass in the third portion of the duodenum

This lesion was thought to explain both his chronic microcytic anemia and his melena, and a malignancy was suspected. Multiple superficial biopsies were taken, which were nondiagnostic. There was no endoscopic evidence to suggest Helicobacter pylori, and its presence was not sought. An abdominal computed tomography scan was obtained (Figure 2), which revealed a mass in the third portion of the duodenum, without any adjacent pancreatic lesions, liver lesions or intra-abdominal lymphadenopathy. The patient was referred for endoscopic ultrasound (EUS). 

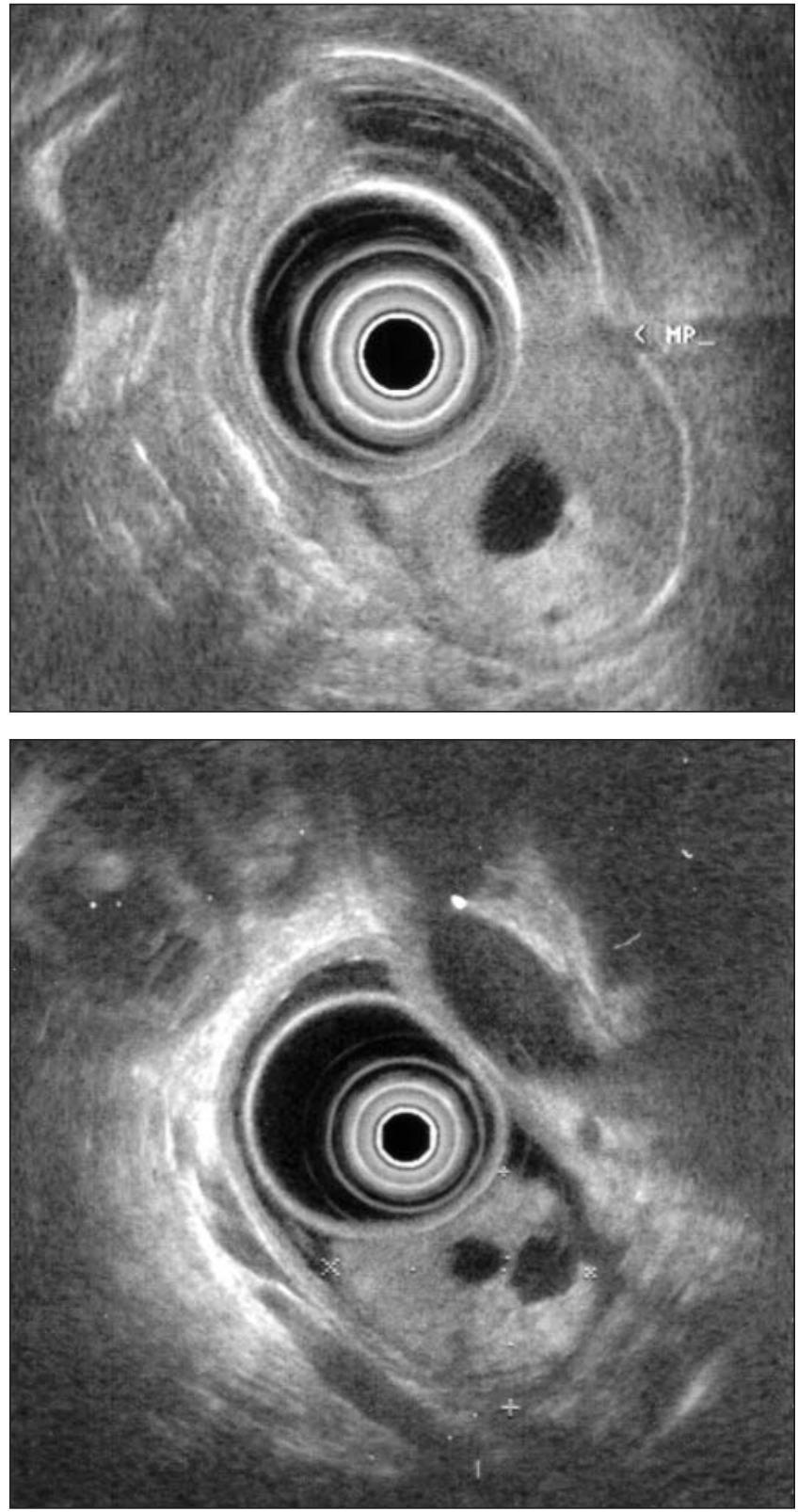

Figure 3) Top Endosonographic image of the Brunner's gland hamartoma showing a $2.7 \times 4.0 \mathrm{~cm}$ lesion arising from the submucosal layer. Note the heterogeneous appearance. MP Muscularis propriae. Bottom Second endosonographic image of the Brunner's gland hamartoma showing hyperechoic features and central cystic areas

With the use of a radial $7.5 \mathrm{mHz}$ echoendoscope (Olympus America, USA), the patient was noted to have a $2.7 \times 4.0 \mathrm{~cm}$ hyperechoic, submucosal tumour in the third portion of the duodenum (Figures 3 ). The lesion had cystic components. It was located distal to the major papilla, and there was no evidence of periampullary, biliary or pancreatic invasion. A malignancy was suspected, especially a gastrointestinal stromal tumour, although a benign lesion such as a lipoma with cystic components could not be discounted. Consequently, fine needle aspiration was performed using a linear array $7.5 \mathrm{mHz}$ echoendoscope (Pentax America, USA) to clarify the lesion further. The fine needle
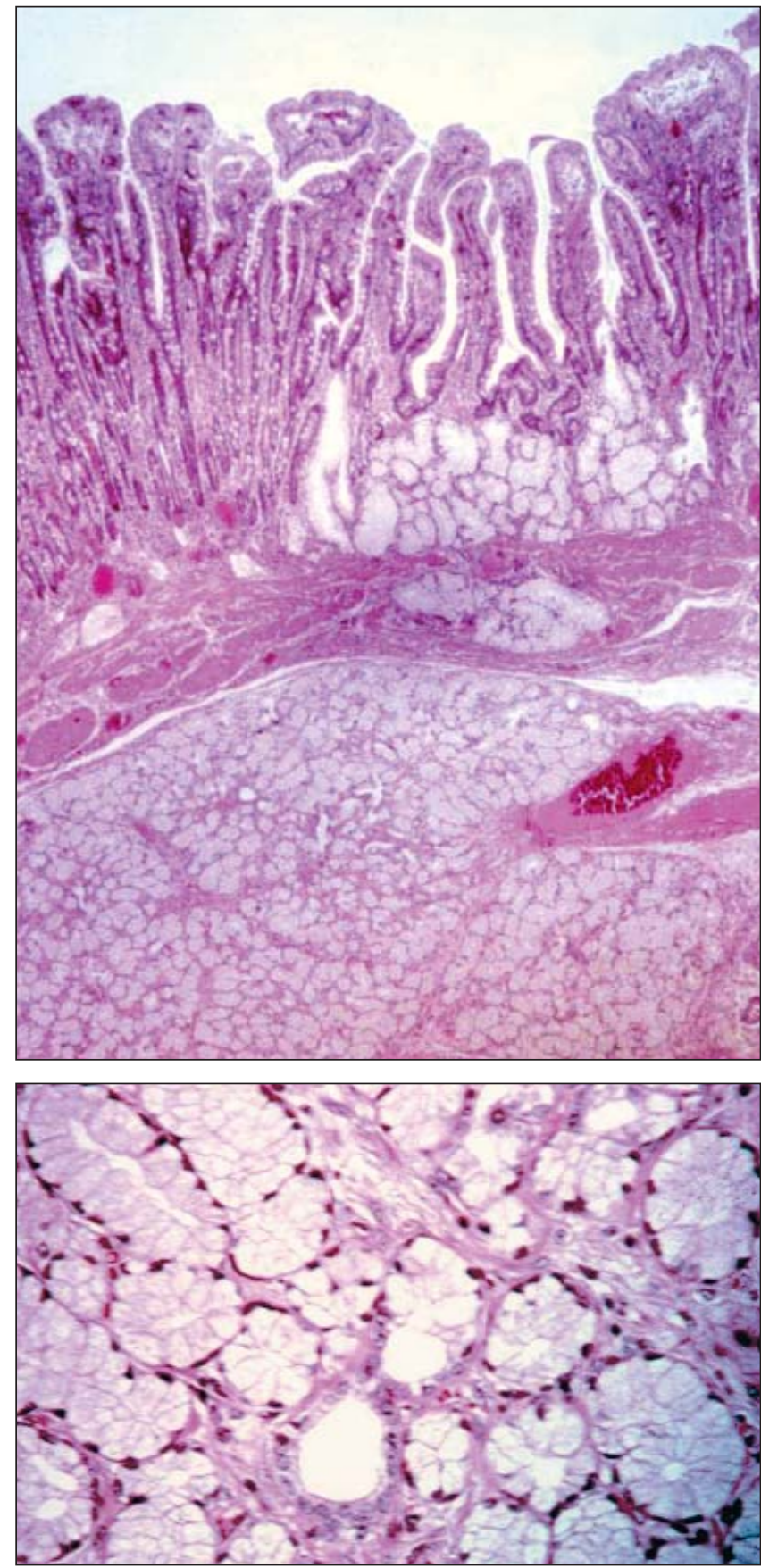

Figure 4) Top Surgical pathology specimen showing the architecture of the Brunner's gland hamartoma (original magnification $\times 50$ ). This slide shows multiple lobules of glands and ducts that retain the appearance of those normally found in Brunner's glands. Bottom High power view (original magnification $\times 400$ ) of a lobule contained within the Brunner's gland hamartoma. This slide shows acini lined by normal appearing ductal cells. Note that the cytoplasm has a foamy appearance and that the nuclei are flattened along the periphery of the cell - an effect that is due to crowding within the lobules

aspiration did not show malignant cells. However, because of continued bleeding, the patient was referred for surgical resection.

He was taken to the operating room and was found to have a $3 \mathrm{~cm}$, ulcerated, submucosal lesion just beyond the 
ampulla of Vater. He subsequently underwent a segmental resection of the third portion of the duodenum, with endto-side duodenoduodenostomy. Surgical pathology revealed that the tumour was a Brunner's gland hamartoma arising from the submucosal layer of the third portion of the duodenum (Figure 4). Two months after surgical resection, the patient was seen during follow-up, at which time, his hemoglobin concentration was normal, at $152 \mathrm{~g} / \mathrm{L}$, suggesting that this lesion was the source of his previous iron-deficiency anemia.

\section{DISCUSSION}

There has been much debate about how best to describe the relatively common occurrence of Brunner's gland proliferation. In 1934, Feyrter (8) classified the proliferation of Brunner's glands into three categories: diffuse hyperplasia, circumscribed hyperplasia and glandular adenoma. More recently, it has been suggested that what Feyrter called the glandular adenoma is better described as a Brunner's gland hamartoma. Supporting evidence includes the lack of encapsulation, the absence of dysplasia and the admixture of tissues including ducts, acini, smooth muscle, adipose tissue, lymphoid tissue and smooth sheets of Brunner's glands, all contained within the pathological structure. As early as 1941, Robertsen (9) argued that the similar histology of these three groups suggested that each might be induced by the same pathological process. It seems reasonable, therefore, that Brunner's gland hyperplasia and the Brunner's gland hamartoma are different but related manifestations of a common etiology.

Although the cause of Brunner's gland hamartomas is unknown, interesting associations have been noted. Because these glands function to buffer the acid output of the stomach, it has been postulated that Brunner's gland hyperplasia (and, by extension, Brunner's gland hamartomas) may be due to hyperchlorhydria $(10,11)$. Although this theory may seem plausible, gastric hyperacidity itself is thought to be an unlikely cause, given that Brunner's gland hyperplasia is not seen in patients with Zollinger-Ellison syndrome. In addition, Spellberg and Vucelic (10) noted that these lesions did not regress after short term cimetidine therapy. Furthermore, Kaplan and colleagues (12) demonstrated, in 1968, that a majority of patients with documented Brunner's gland hyperplasia did not have increased gastric acid output. Interestingly, Tottrup, et al (11) questioned whether hyperplasia of Brunner's glands might actually lead to gastric hyperacidity (and not the other way around). They noted that hyperplasia of these glands is associated with subsequent proliferation of duodenal gastrin cells; this may lead to increased gastrin secretion and, consequently, an increase in gastric acid output.

In addition, an association between chronic pancreatitis and Brunner's gland hyperplasia may exist. As many as 76\% of patients with pancreaticoduodenal resections for chronic pancreatitis show evidence of diffuse Brunner's gland hyperplasia (13), and some suggest that this may be an adaptation in the setting of exocrine insufficiency of the pancreas.
The differential diagnosis of the Brunner's gland hamartoma includes adenomatous polyps, leiomyomas, leiomyosarcomas, gastrointestinal stromal tumours, lymphomas, pancreatic or ampullary carcinomas, carcinoid tumour or melanoma, among others.

The diagnosis of a Brunner's gland hamartoma should be considered for any polypoid lesion in the duodenum. These lesions may appear either sessile or pedunculated; one series of 27 patients noted that the lesions were pedunculated in $89 \%$ of cases (14). As mentioned previously, most Brunner's gland hamartomas occur in the proximal duodenum; the same series of 27 patients found that $70 \%$ had a hamartoma in the bulb, $26 \%$ in the second portion and $4 \%$ in the third portion (14). Because these lesions tend to be submucosal, routine endoscopic biopsies may not be adequate for establishing the diagnosis, and further studies are often required. Because EUS is considered to be the best modality to image submucosal structures, it has become the imaging modality of choice.

EUS may be helpful in establishing a preliminary diagnosis by evaluating characteristics of the mass. Certain lesions tend to have reproducible characteristics on endosonography, and the Brunner's gland hamartoma is no exception. Whereas a typical Brunner's gland appears as a heterogeneous hyperechoic structure, the Brunner's gland hamartoma appears as a heterogeneous hypoechoic mass marked by multiple small cystic areas within the lesion and indistinct margins. Furthermore, it characteristically arises from the second and third echolayer (15). The multiple small cystic areas and the heterogeneity seen on EUS are secondary to the presence of smooth muscle bundles, fibrous stoma and clusters of glands within the lesion, some of which may be dilated.

Of course, the definitive diagnosis depends on histological evaluation. Characteristics include a well circumscribed, nonencapsulated lesion with lobular architecture, in which glandular structures may be embedded in fibrous stroma. Normal-appearing Brunner's glands are typically present, as are variable combinations of ducts, smooth muscle, adipose tissue, sclerotic glands and lymphoid aggregates $(1,13)$.

Because of the benign nature of Brunner's gland hamartomas, in most cases, therapy should be reserved for lesions that have become symptomatic. The traditional approach has been surgical excision through a duodenotomy or segmental duodenal resection. Recently, however, endoscopic polypectomy has been been shown to be safe and effective, and may be associated with decreased morbidity, shortened hospital stay and reduced cost $(5,6)$. In the present case, the large size of the lesion, coupled with its location in the thinwalled third portion of the duodenum, would have made endoscopic mucosal resection difficult and potentially dangerous; therefore, it was not attempted.

\section{CONCLUSIONS}

The present case demonstrates a benign Brunner's gland hamartoma presenting in a middle-aged man, with evidence of both chronic gastrointestinal blood loss as well as 
acute upper gastrointestinal bleeding. Although in this case, the diagnosis was not known before surgical resection, the benign nature of the lesion was suspected. Because of the symptomatic nature of the lesion, therapy was indicated. In the future, given the known endosonographic characteristics of this lesion, we believe that EUS may hold promise in establishing the diagnosis of these lesions before potentially risky and unnecessary surgical resection, especially with smaller lesions, or in cases in which the patient is asymptomatic.

\section{REFERENCES}

1. Zangara J, Kushner H, Drachenberg C, Daly B, Flowers J, Fantry G. Iron deficiency anemia due to a Brunner's gland hamartoma. J Clin Gastroenterol 1998;27:353-6.

2. Bostford TW, Crowne P, Crocker DW. Tumors of the small intestine. Am J Surg 1962;103:358-65.

3. Attanoos R, Williams GT. Epithelial and neuroendocrine tumors of the duodenum. Semin Diagn Pathol 1991;8:1439-162.

4. Levine JA, Burgait LJ, Batta KP, Wang KK. Brunner's gland hamartomas: clinical presentation and pathological features of 27 cases. Am J Gastroenterol 1995;90:290-4.

5. Khawaja HT, Deakin M, Colin-Jones DG. Endoscopic removal of a large ulcerated Brunner's gland adenoma. Endoscopy 1986;18:199-201. 6. Tai M, Yoshikawa I, Kume K, Murata I, Otsuki M. A large Brunner's gland hamartoma resected by endoscopic polypectomy. Gastrointest Endosc 2001;53:2:207-8.

7. Block KP, Frick TJ, Warner TFSC. Gastrointestinal bleeding from a Brunner's gland hamartoma: characterization by endoscopy, computed tomography, and endoscopic ultrasound. Am J Gastroenterol 2000;95:1581-3.

8. Feyrter F. Gber Wucherungen der Brunnerschen Drhsen. Virchows Arch (Pathol Anat) 1934:293:509-26.

9. Robertson HE. The pathology of Brunner's glands. Arch Pathol 1941;31:112-29.

10. Spellberg MA, Vucelic B. A case of Brunner's gland hyperplasia with diarrhea responsive to cimetidine. Am J Gastroenterol 1980;73:519-22.

11. Tottrup A, Rokkjaer M, Kruse A, Poulsen SS, Jacobsen NO. Excessive nodular hyperplasia of Brunner glands associated with gastric hypersecretion and lipomatous atrophy of the pancreas. Scand J Gastroenterol 1999;34:541-4.

12. Kaplan EL, Dyson WL, Fitts WT Jr, et al. Hyperplasia of Brunner's glands of the duodenum. Surg Gynecol Obstet 1968;126:371-5.

13. Stolte M, Schwabe H, Prestele H. Relationship between diseases of the pancreas and hyperplasia of Brunner's glands. Virchows Arch A Pathol Anat Histopathol 1981;394:75-87.

14. Levine JA, Burgait LJ, Batta KP, Wang KK. Brunner's gland hamartomas: clinical presentation and pathological features of 27 cases. Am J Gastroenterol 1995;90:290-4.

15. Matsushita M, Takakuwa H, Nishio A. Endosonographic features of Brunner's gland hamartoma: location within the fourth echolayer? Am J Gastroenterol 2001;96;4:1302-3. 


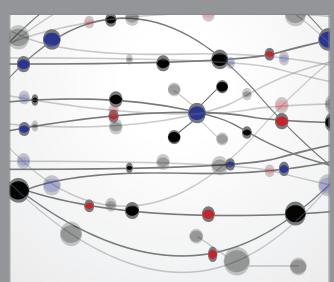

The Scientific World Journal
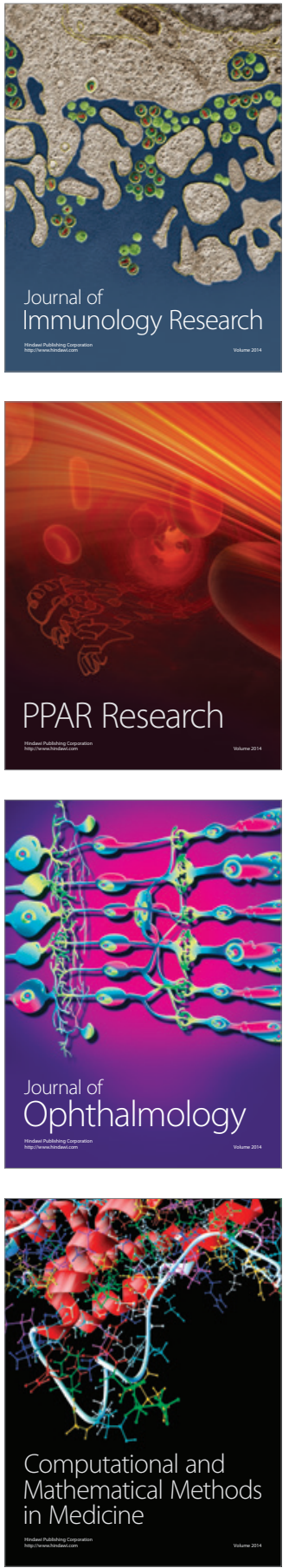

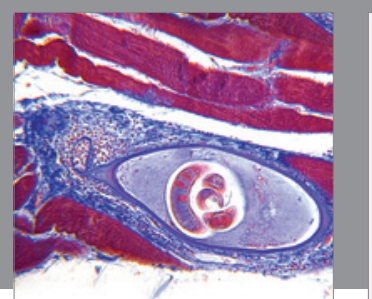

Gastroenterology Research and Practice

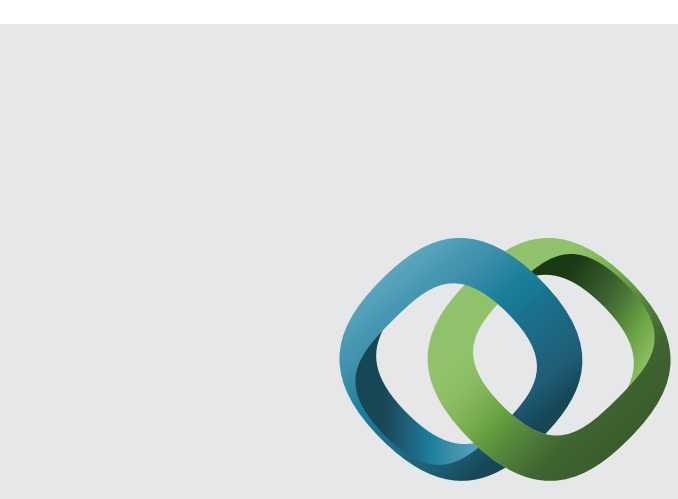

\section{Hindawi}

Submit your manuscripts at

http://www.hindawi.com
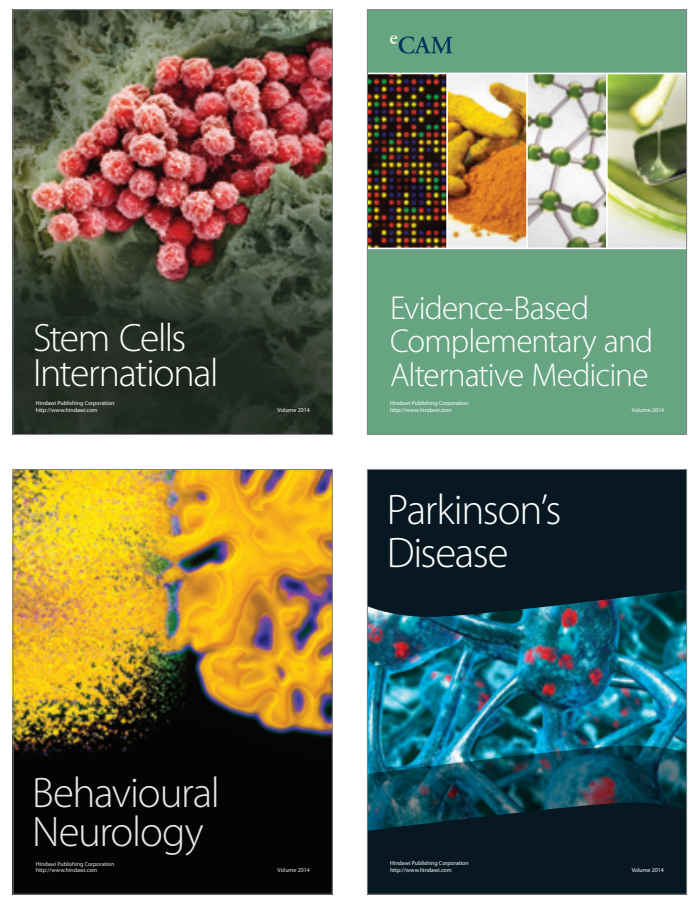
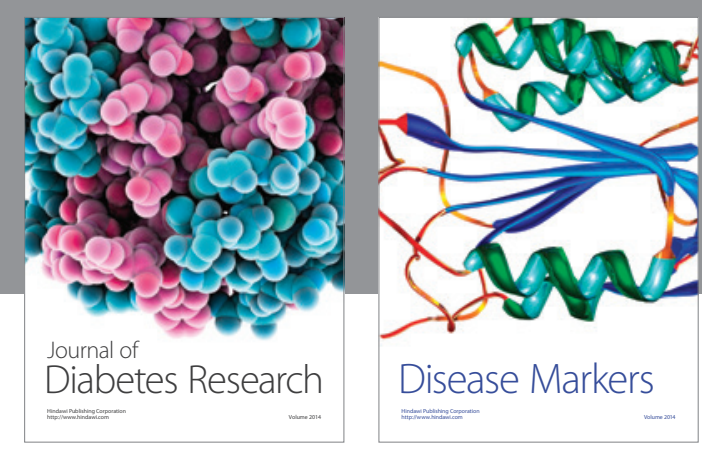

Disease Markers
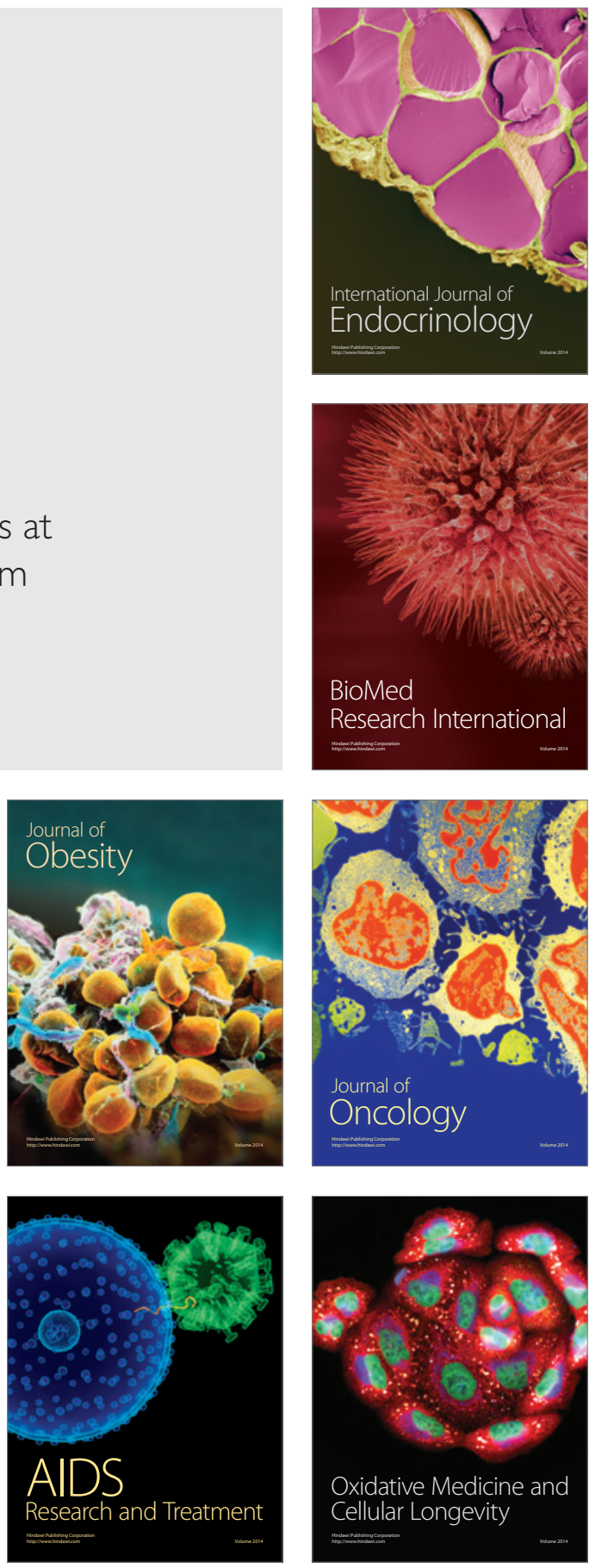